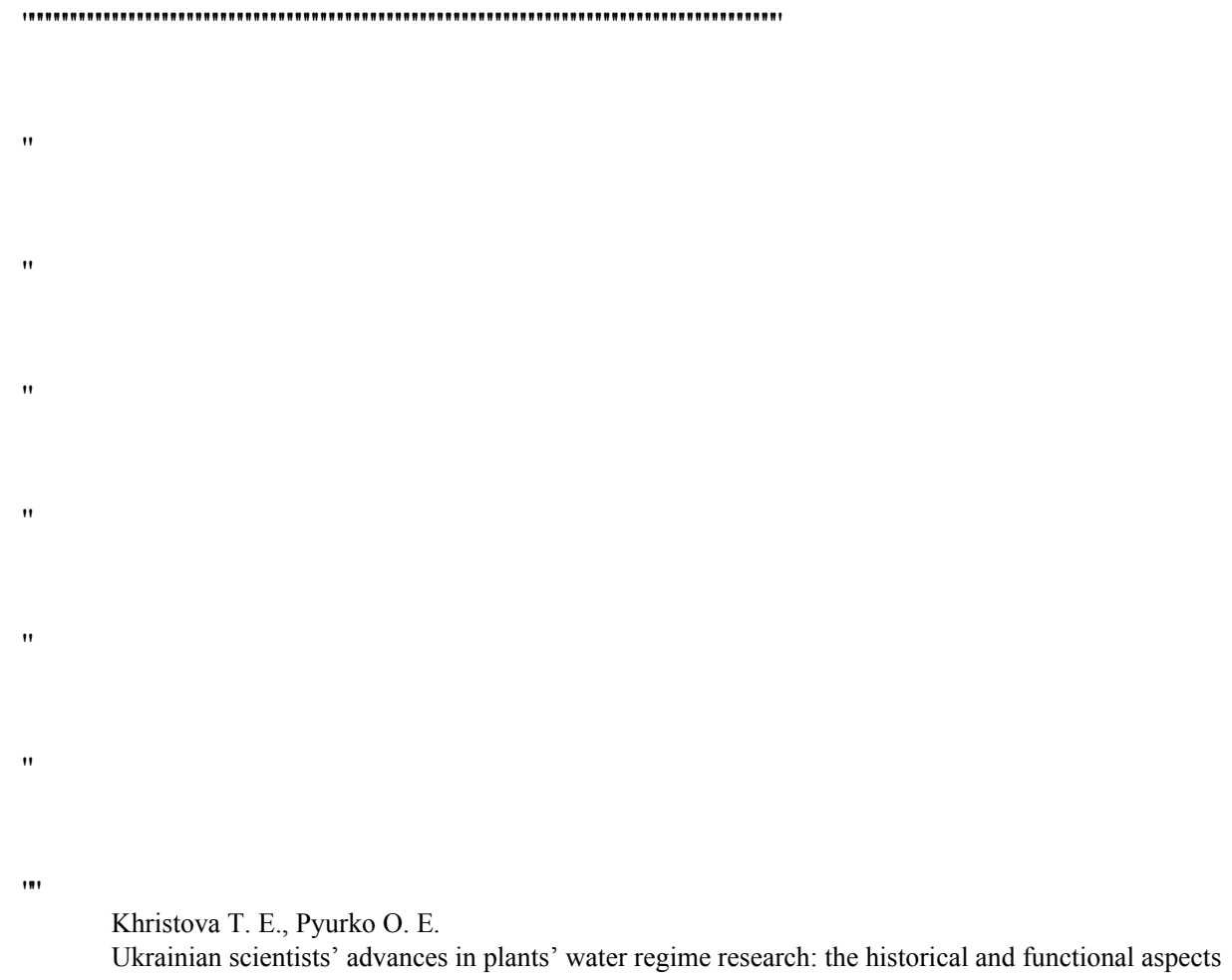

УДК 581.1 : 632.112 (091) (477)

Т. Є. Христова, О. Є. Пюрко

Київський національний університет ім. Т. Шевченка

Мелітопольський державний педагогічний університет

\title{
ПИТАННЯ ВОДНОГО РЕЖИМУ РОСЛИН У ПРАЦЯХ ВІТЧИЗНЯНИХ ФІТОФІЗІОЛОГІВ: ІСТОРИЧНО-ФУНКЦОНАЛЬНИЙ АСПЕКТ
}

В історично-функціональному аспекті показано досягнення вчених України у розробці водного режиму рослин. Вітчизняні дослідники внесли суттєвий вклад у розвиток різних напрямків даної проблеми: створення та вдосконалення матеріально-технічної бази; розробки та використання сучасних методів вивчення водного режиму рослин; отримання надійної інформації у теоретичному та практичному контекстах.

Achievements of Ukrainian scientists in advances of plants' water regime research from the standpoint of historical and functional aspects are represented. It is shown that they made essential contribution to the different developments of this problem: creation and improvement of material and technical resources, elaboration and using of modern methods of plants' water regime research, gain of important information in theoretical and practical contexts.

\section{Ветуп}

Вода для рослин, з одного боку, є фактором зовнішнього середовища, вплив якого має як позитивний (вона необхідна для прояву всіх процесів життєдіяльності), так і негативний характер (ії надлишок обумовлює гіпоксію та енергетичний голод),

Вісник Дніпропетровського університету. Біологія, екологія.

Vìsnik Dnìpropetrovs'kogo unìversitetu. Serìa Bìologiâ, ekologiâ

Visnyk of Dnipropetrovsk University. Biology, ecology. Vìsn. Dnìpropetr. Unìv. Ser. Bìol. Ekol. 2007. 15(1).

ISSN 2310-0842 print ISSN 2312-301X online www.ecology.dp.ua 
а 3 іншого - формує необхідне внутрішнє середовище для здійснення біохімічних реакцій та фізіологічних процесів. При цьому вода виступає як безпосередній учасник (фотосинтез, процеси синтезу та гідролізу тощо) або $є$ кінцевим продуктом (процеси дихання, окислення, нейтралізації тощо) і тому виконує функцію одного з основних екологічних факторів, який обумовлює розподіл рослинних організмів по Земній кулі, особливості їх росту, розвитку та формування не тільки біологічного, а й господарського врожаю. У зв'язку з цим питання водного режиму рослин завжди цікавили науковців, у тому числі й вітчизняних, не тільки в теоретичному та практично-прикладному аспектах, а й у історико-функціональному контексті [29].

Головна мета даної роботи полягає в узагальненні та систематизації наукових здобутків, особливо вітчизняних фітофізіологів, стосовно питань водного режиму рослин як одного 3 провідних факторів забезпечення їх життєдіяльності та біопродуктивності.

Першочергові завдання роботи - вивчення основних етапів формування вчення про водообмін у хронологічному порядку, з'ясування його головних напрямків і превалюючих тенденцій у кожному конкретному періоді часу, аналіз внеску окремих вітчизняних вчених і наукових шкіл, узагальнення значення їхніх робіт у формуванні сучасного вчення про водообмін рослин.

\section{Становлення вчення про водообмін рослин}

В узагальненому вигляді весь процес становлення вчення про водообмін рослин можна поділити на такі, відносно самостійні, але хронологічно взаємопов'язані та взаємообумовлені періоди.

I період - натуралістично-філософський (від початку нашої ери до X століття) - характеризується поступовим накопиченням інформації про воду та поширенням застосування іiі в землеробстві, а також формуванням простих філософських узагальнень стосовно іï суті.

II період (XI-XV століття) відомий як період домінування теологічних тлумачень явищ природи без обгрунтувань і пояснень та початку перших наукових досліджень водообміну.

III період (XVI-XVII століття) вважається “колискою сучасної науки”, тому що відбувається перегляд теологічних уявлень, у тому числі й стосовно води: Р. Декартом формується гіпотеза про склад води 3 окремих часток, які легко відокремлюються, і процес випаровування пояснюється наявністю легких часток, які під дією енергії сонця починають рухатися; Б. Маріоттом обгрунтовується кругообіг води у природі; Б. Кастеллі формулюється принцип безперервності потоку води та п'ять аксіом стосовно залежності швидкості течії води від площі отворів; на основі експериментальних результатів формуються базові положення про воду (властивості, стан, знаходження у природі, зміни ії кількості в опадах тощо).

IV період (XVIII століття) характеризується виділенням фізіології рослин у самостійну науку; домінуванням запропонованої Я. Б. ван Гельмонтом “водної” теорії живлення рослин; початком формування осмотичного та колоїдно-хімічного етапів досліджень водообміну рослинних організмів.

$\mathrm{V}$ період (XIX століття) відзначається становленням фізіології рослин як самостійної науки в Україні; інтенсифікацією розвитку вчення про водообмін і його вплив на основні процеси життєдіяльності рослин; домінуванням осмотичного та колоїдно-хімічного i початком формування термодинамічного, біохімічного та біофізичного етапів досліджень водообміну; теоретичним обгрунтуванням агрономічних заходів щодо раціонального використання рослинами природних ресурсів.

Вісник Дніпропетровського університету. Біологія, екологія.

Vìsnik Dnìpropetrovs'kogo unìversitetu. Serìa Bìologîa, ekologîâ Visnyk of Dnipropetrovsk University. Biology, ecology. Vìsn. Dnìpropetr. Unìv. Ser. Bìol. Ekol. 2007. 15(1).

ISSN 2310-0842 print ISSN 2312-301X online www.ecology.dp.ua 
VI період (XX століття до сьогодення) визначається домінуванням термодинамічного, біохімічного та біофізичного етапів досліджень водного режиму рослин, формуванням їх фундаментальних положень та з'ясуванням молекулярних основ; розробкою методів та способів свідомого керування продуктивністю рослин за рахунок ї водного режиму; формуванням математичних узагальнень, програмування, прогнозування, кібернізації.

Кожний із періодів визначається відповідним рівнем розвитку суспільства, станом науки, матеріально-технічним забезпеченням i, головне, - запитами суспільства та його інтелектуальним потенціалом. Тому не випадково, що перші зазначені періоди були найбільш тривалими та найменш результативними стосовно формування вчення про водообмін рослин. У подальшому тривалість періодів зменшується на фоні значного підвищення обсягу та якості наукової інформації стосовно водного режиму рослин. За рахунок технічного прогресу удосконалюються методи досліджень, уточнюються відомі та відкриваються нові закономірності, розширюються контакти з іншими напрямками та дисциплінами, на основі кооперативних експериментальних результатів формується сучасна теорія водообміну рослин. Переконлива ілюстрація вищезазначеного - матеріали узагальнювальної схеми, складеної нами (рис. 1) [24].

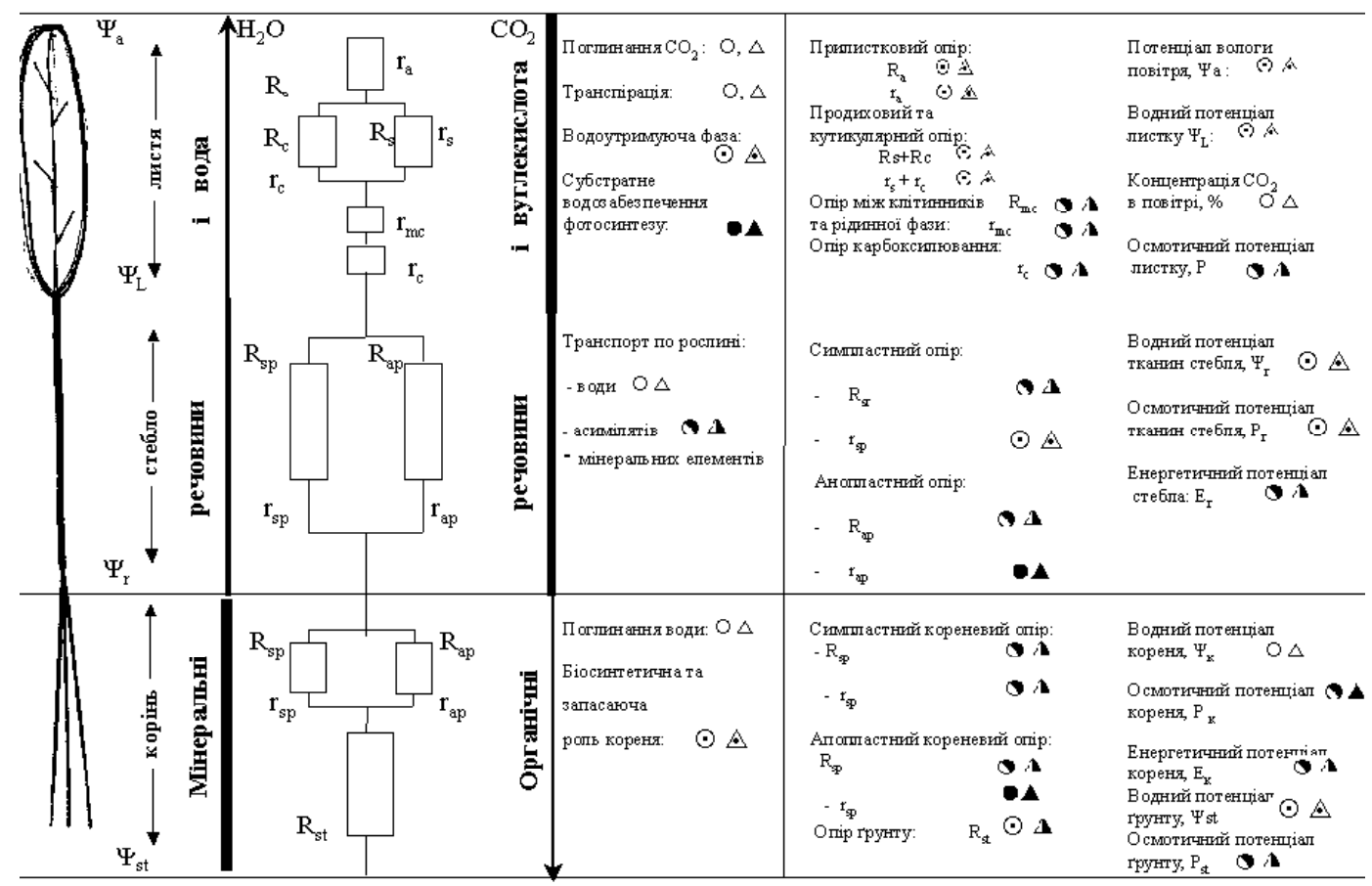

Рис. 1. Узагальнювальна схема стану розробки методів та ступеня вивченості взаємозв'язків фотосинтетичного процесу та водного режиму у рослин: методи: О - розроблені, $\odot$ - інтенсивно розробляються, $\odot$ - перспективні, але недостатньо розроблені, $\bullet$ - майже не розроблені; процеси: $\triangle$ - вивчені;

$\triangle$ - інтенсивно вивчаються, $\boldsymbol{\wedge}$ - важливі, але недостатньо вивчені, $\boldsymbol{\wedge}$ - майже не вивчені

Ці матеріали дозволяють констатувати, що і нині вирішені далеко не всі проблеми водного режиму рослин. У зв'язку з цим розробка методів вивчення водообміну на різних рівнях організації рослинного організму продовжується й у результаті з'ясовуються нові деталі та закономірності цього важливого процесу [14; 22].

Вісник Дніпропетровського університету. Біологія, екологія.

Vìsnik Dnìpropetrovs'kogo unìversitetu. Serîâ Bìologîa, ekologiâ Visnyk of Dnipropetrovsk University. Biology, ecology. Vìsn. Dnìpropetr. Unìv. Ser. Bìol. Ekol. 2007. 15(1).

ISSN 2310-0842 print ISSN 2312-301X online www.ecology.dp.ua 
В Україні фізіологія рослин як самостійна наука почала формуватися з середини XIX сторіччя, а згодом виникли і її окремі напрями, зокрема, водний режим рослин (V період). Перші цеглини у становленні цього напрямку закладені київськими вченими: С. М. Богдановим, Й. В. Баранецьким, Є. П. Вотчалом, В. Р. Заленським, В. В. Колкуновим та іншими [17]. С. М. Богданов уперше встановив мінімум води, необхідний для проростання насіння різних культур; показав на основі осмотичних явищ залежність між хімічним складом насіння та потребою його у воді, сформулював вчення про “мертвий запас води у грунті” [4].

Значний вклад у розвиток теорії водообміну рослин вніс Й. В. Баранецький, який окреслив новий напрямок у розвитку цієї науки. У 1871 році вчений розпочав роботи з екологічної фізіології рослин, а саме - вивчення впливу різних умов на випаровування води рослинами. Й. В. Баранецьким установлено, що транспірація обумовлюється впливом різних факторів, до яких належать зміни умов освітлення, струшування пагонів, при якому водяна пара виходить швидше 3 повітряних порожнин рослин. У своїх працях він довів пряму залежність випаровування води рослинами від зовнішніх умов [39]. Й. В. Баранецькому належить пріоритет у виявленні періодичності соковиділення рослин, встановленні його причин та залежності від температури. Він з'ясував, що періодичність “плачу” рослин обумовлюється змінами дня та ночі, освітленням та затемненням. Дослідження цього періоду покладено в основу докторської дисертації “О периодичности “плача" у травянистых растений и причинах этой периодичности”[3], яку він захистив у 1873 році, після чого очолив кафедру фізіології рослин у Київському університеті, працював ії завідувачем упродовж 25 років. Його по праву вважають одним із фундаторів фізіології рослин в Україні.

Великий вклад у розвиток вчення про водообмін рослин внесли роботи Є. П. Вотчала, який після закінчення Казанського університету розпочав викладацьку діяльність у сільськогосподарському інституті Нової Олександрії, а потім очолив кафедру фізіології рослин у Київському політехнічному інституті. У 1897 році він опублікував капітальну працю стосовно пересування води по стовбурах дерев магістерську дисертацію “О движении воды (пасоки) в растениях", але завдяки важливості роботи йому був присвоєний ступінь доктора наук. У своїх дослідженнях фітофізіолог використовував методику автоматичного запису змін тиску у судинах ксилеми, по яких пересувалась вода. Він установив пасивну роль деревини у транспорті води та сформулював основні положення теорії підняття води по рослині, яка пояснює це явище роботою верхнього та нижнього кінцевих двигунів і навіть нині не втратила актуальності [6]. Є.П. Вотчал сконструював термоголку - прилад для вимірювання дійсної температури листка з великою точністю, який забезпечував запис на самописці кривих зміни температури листка за різної динаміки змін факторів довкілля. Він одним із перших запропонував систему одночасних комплексних досліджень рослин (реєстрацію декількох фізіологічних параметрів), які забезпечують відносно нормальну їх життєдіяльність за певних умов середовища. За участі однодумців та співробітників (В. Р. Заленського, І. М. Толмачова, А. С. Оканенка, А. М. Кекуха та ін.) у польових умовах за допомогою розроблених методів вивчалися фотосинтез, дихання, транспірація, зміни температури, тургору, кольору та блиску листків цукрових буряків за умов різного водозабезпечення. Встановлено, що дефіцит води при підвищеній сонячній інсоляції обумовлює розлад водного балансу рослинного організму, пригнічує газообмін (фотосинтез і випаровування), підсилює дихання $\mathrm{i}$, як наслідок, значно знижує продуктивність рослин [7].

Учнем та послідовником С. П. Вотчала був В. Р. Заленський, який теж закінчив Казанський університет і певний час (1889-1908 рр.) працював у Київському полі- 
технічному інституті, де і виконав магістерську роботу з теми "Материалы к количественной анатомии различных листьев одних и тех же растений”. Його дослідженнями встановлено, що при переході від листків нижніх ярусів до верхніх спостерігаються певні закономірності: анатомо-морфологічні - зменшуються розміри продихів та клітин епідермісу, густішим стає жилкування, збільшується кількість продихів на одиницю поверхні; фізіологічні - активніше протікають процеси асиміляції вуглекислоти і транспірації, підвищується концентрація клітинного соку та осмотичний тиск, виявляється більша стійкість при зав'яданні рослини. В. Р. Заленський установив важливі закономірності залежності анатомо-морфологічних параметрів від зовнішніх факторів середовища та узагальнив їх у вигляді вчення про “функціональний ксероморфізм" та "закону Заленського" [15]. Дослідження цього талановитого вченого були продовжені у працях В. В. Колкунова, який висунув ідею про добір посухостійких рослин на основі вивчення анатомічних пристосувань проти посухи; був визнаний як автор популярної у свій час анатомо-морфологічної теорії посухостійкості [25].

Цей період розвитку вчення про водообмін у рослин характеризувався пошуком молекулярних механізмів поглинання та утримання води у клітині, рослині і тому поступово осмотичний

$$
P=i C R T \text {, }
$$

де $P$ - осмотичний потенціал (МПа), $i$ - ізотонічний коефіцієнт Вант-Гоффа, який характеризує ступінь іонізації розчиненої речовини (для неелектролітів дорівнює 1), $C$ - молярна концентрація розчину (моль/л), $R$ - газова стала (яка дорівнює 0,08205 ), $T$ - абсолютна температура за Кельвіном $\left(273^{\circ}+\right.$ температура у період досліджень)) та колоїдно-хімічний

$$
£=\left[\left(m-m_{0}\right) \cdot m^{-1}\right] \cdot 100,
$$

де $£$ - ступінь набрякання гелю (\%), $m_{0}, m$ - маса гелю до та після набрякання (г), 100 - коефіцієнт переведення значень у \%) механізми замінюються термодинамічним, основним параметром якого $є$ водний потенціал.

Перші кроки у напрямку розробки термодинамічних понять та введення відповідної термінології зроблені Г. Вальтером, А. М. Алексєєвим, В. С. Шардаковим [2; 12; 35]. У 1931 році Г. Вальтер запропонував як об'єктивний показник ступеня насиченості рослин водою гідратуру - відношення пружності водяної пари над поверхнею конкретного тіла до пружності водяної пари над чистою водою. Це відношення виражається відсотками від останньої величини та являє собою ту відносну вологість повітря, при якій тіло не віддає воду в навколишній простір і не поглинає іiї 3 нього. В найбільшій мірі термодинамічний підхід до вивчення водного режиму рослин застосував А. М. Алексєєв [2], який сформулював поняття активності води та парціального хімічного потенціалу. Останні повинні характеризувати процеси переходу води з однісї фази в іншу, осмос, пароутворення, процеси на поверхні розділу, участь води у хімічних реакціях і механічних переміщеннях.

Найширше застосування знаходить хімічний потенціал води ( $\mu \mathrm{w})$, що характеризує максимальну кількість внутрішньої енергії молекул, яка може бути перетворена на роботу. Він має розмірність кал/моль або Дж/моль і розраховується за формулою:

$$
\mu_{w}=\mu_{w}^{0}+R \cdot T \cdot \ln a_{w},
$$

де $\mu_{w}^{0}$ - хімічний потенціал чистої води, $R$ - газова стала, $T$ - абсолютна температура, $\ln a_{w}$ - активність води у системі. У розчинах і клітинах $a_{w}$ менше одиниці, тому $\ln a_{w}-$ величина від'ємна; хімічний потенціал клітинного соку менший, ніж у чистої води.

Вісник Дніпропетровського університету. Біологія, екологія.

Vìsnik Dnìpropetrovs'kogo unìversitetu. Serìa Bìologiâ, ekologîâ Visnyk of Dnipropetrovsk University. Biology, ecology. Vìsn. Dnìpropetr. Unìv. Ser. Bìol. Ekol. 2007. 15(1).

ISSN 2310-0842 print ISSN 2312-301X online www.ecology.dp.ua 
Водний потенціал ( $\psi$ ) показує здатність води у даній системі здійснювати роботу порівняно з тією роботою, яку при тих самих умовах здійснила чиста вода. Він розраховується за рівнянням:

$$
\psi=\left(\mu_{w}-\mu_{w}^{0}\right) / \bar{U}_{w},
$$

де $\mu_{w}$ - хімічний потенціал води у системі, $\mu_{w}^{0}-$ хімічний потенціал чистої води, $\bar{U}_{w}-$ парціальний мольний об'єм води (для чистої води та розбавлених розчинів $\bar{U}_{w} \approx$ $18,0 \mathrm{~cm}^{3}$ /моль). Водний потенціал має розмірність енергії, поділеної на об'єм, і тому може бути представлений у атмосферах, барах або паскалях $(1$ ат $=1,013$ бар = $0,1 \mathrm{MПа)} \mathrm{[12;16].}$

Біохімічний етап розвитку досліджень водообміну рослин характеризується 3'ясуванням біохімічної ролі води у різних ланцюгах обміну речовин рослинного організму (фотосинтезі, диханні, ферментативних реакціях синтезу, гідролітичних процесах тощо). Встановлено, що за рівнянням фотосинтезу

$$
6 \mathrm{CO}_{2}+12 \mathrm{H}_{2} \mathrm{O} \underset{\text { пімент }}{\stackrel{h v}{\longrightarrow}} \mathrm{C}_{6} \mathrm{H}_{12} \mathrm{O}_{6}+6 \mathrm{H}_{2} \mathrm{O}+6 \mathrm{O}_{2} \quad(\Delta G+686 \kappa \kappa \text { кл/ моль })
$$

вода необхідна не тільки для утворення молекул глюкози, а і для здійснення проміжних реакцій фотосинтезу. При цьому шість молекул $\mathrm{H}_{2} \mathrm{O}$ у правій частині рівняння можуть бути знову використані у темнових реакціях при дефіциті або включатися в транспіраційний процес при достатньому водозабезпеченні. Незважаючи на різні шляхи використання молекул води з правої частини рівняння, на початку реакцій (ліва частина) вони повинні обов'язково бути для того, щоб фотосинтез дійшов до своєї завершальної стадії - утворення кінцевих продуктів [14]. На необхідність молекул води для здійснення дихання вказував В. І. Палладін, який у 1912 році розділив основне рівняння дихання на анаеробну та аеробну фази. У цій теорії дихання велике значення належить процесам активування водню як окислювального субстрату, так і водню води (12 молекул), і в подальшому перенесенні останнього за участю окисно-відновних систем [30].

Початок застосування біофізичних методів вивчення водообміну у рослин припадає на кінець п'ятого і початок шостого періодів. Методами ядерного магнітного резонансу (ЯМР), електронного парамагнітного резонансу (ЕПР), мічених атомів з'ясовуються механізми транспорту води по рослині, встановлюються симпластний та апопластний шляхи транспорту води по рослині, розкриваються механізми фотолізу води та походження кисню з води, який виділяється при фотосинтезі, та багато інших наукових питань. Незважаючи на основний екологічний напрямок наукових досліджень в Україні, вченими інтенсивно та досить ефективно розробляються інші важливі питання водного режиму рослин, зокрема розподіл води за компартментами клітин, тканинами та органами рослини, водовитрати за різні проміжки часу, продуктивність водовитрат [23] залежно від водозабезпечення на різних типах грунтів [38].

Найбільшої уваги заслуговують дослідження цих напрямків у створеному в 1946 році на базі відділу фізіології живлення рослин та агрохімії Інституту ботаніки АН УРСР нового Інституту фізіології рослин і агрохімії АН УРСР, який входив до складу Української академії сільськогосподарських наук і називався Український науково-дослідний інститут фізіології рослин, а у 1962 році він був переданий Академії наук УРСР під назвою Інститут фізіології рослин АН УРСР. У кінці 1940-х років у цьому науково-дослідному закладі під керівництвом Т. Т. Демиденка була виконана низка робіт, присвячених водному режиму та посухостійкості рослин. У 1959 році розпочато дослідження стійкості озимої пшениці до посухи у зв'язку з сортовою специфічністю (П. А. Власюк, Д. П. Проценко, І. Г. Шматько та інші) [34].

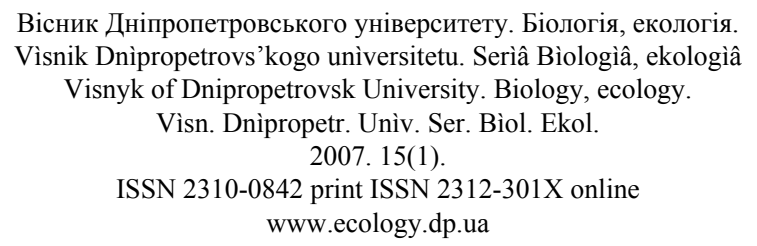


У 1968 році у ІФР АН УРСР під керівництвом С. І. Слухая створено відділ водного режиму рослин, основним напрямком роботи якого було вивчення водного режиму рослин у зв'язку з різним забезпеченням їх елементами мінерального живлення за богарних умов і при зрошенні.

У 1973 році відділ очолив доктор біологічних наук І. Г. Шматько. Він розгорнув роботи з вивчення генотипових особливостей водообміну культурних рослин. Завдяки використанню сучасних методів досліджень водного режиму (ЯМРспектроскопії, застосуванню дейтерієвої та тритієвої води, міченого азоту та інших) була отримана важлива інформація про стан води у зернівках і меристематичних тканинах, про особливості функціонування симпластного та апопластного шляхів транспорту води, про взаємозв'язок водообміну з метаболічними процесами за умов різного водозабезпечення. Запропоновано нові методи оцінки та підвищення стійкості рослин озимої пшениці та картоплі до посухи. Досліджено генотипні особливості складу вільних амінокислот і амідів у листках гібридів кукурудзи при різному водозабезпеченні, особливості функціонування продихового апарата пшениці за умов дії посухи та високих температур [28; 37; 38].

У 1996 році зазначений відділ очолив доктор біологічних наук І. П. Григорюк. Під його керівництвом досліджено системи регуляції та механізми стійкості рослин до водного та високотемпературного стресів. Уперше сформульовано і теоретично обгрунтовано концепцію застосування полімерних регуляторів росту 3 фітогормональною активністю для індукції адаптивних реакцій та регуляції систем водообміну рослин за умов дії несприятливих факторів. 3'ясовано, що стійкість рослин до вищезгаданих чинників обумовлена характером кристалізації та деструкції полярних ліпідів у мембранах хлоропластів, станом пластидного апарата та динамічними перебудовами водного, енергетичного та фітогормонального балансу [8; 33]. Розкрито явище автономності та універсальності фізіологічних функцій, що призвело до конкретизації уявлень про внутрішньоклітинну організацію метаболізму та інтегральну регуляцію у системі цілісної рослини за стресових умов. Уперше оцінено величини пулу функціональних фітогормонів і активність кожного з них у процесі адаптації рослин до водних стресів. Виявлено взаємозв'язок між водним і поверхневим біопотенціалами та продуктивність використання води за умов обмеженого водозабезпечення [9].

У 2005 році відділ очолила доктор біологічних наук О. I. Жук, під керівництвом якої розгорнуто роботи 3 оцінки вкладу проліферативної складової клітинного росту в адаптивні і відновні процеси в апікальних та інтеркалярних меристемах рослин за дії дефіциту води та підвищених температур [13]. Вченими відділу вперше переконливо показано, що дефіцит вологи більше впливає на фазу розтягнення клітин (при $\psi=-0,80-1,10$ МПа розтягнення припиняється зовсім), ніж на фазу їх поділу (при $\psi=-1,27-1,30$ МПа поділ клітин дуже повільний, але продовжується) і тому узагальнювальний параметр - ріст - лімітується як фазою поділу, так і фазою розтягнення, але останньою - найбільше [30]. Протягом останнього десятиріччя співробітниками відділу опубліковано 102 статті, методичний посібник, 2 брошури, 5 методичних рекомендацій; захищено 3 докторські та 7 кандидатських дисертацій; отримано авторське свідоцтво на винахід і 2 патенти України. За цикл праць «Водообмін та посухостійкість рослин» І. Г. Шматьку, І. П. Григорюку та О. Ю. Шведовій у 1991 році присуджено премію імені М. Г. Холодного АН України [27].

Фізіологічні особливості злаків при різній водозабезпеченості у 1958-1973 pp. вивчались у Всесоюзному науково-дослідному інституті кукурудзи (А. І. Задонцев, Г. Л. Філіппов та ін.), Київському університеті (А. В. Капля, М. М. Мусієнко, 
П. С. Славний та ін.) [30; 34], багаторічних деревних культур - у Державному Нікітському ботанічному саду (Г. М. Єремєєв, Є. Я. Яблонський).

Заслуговують на увагу аматорські розробки вітчизняних вчених стосовно автоматизованої підтримки заданих рівнів вологості грунту не тільки впродовж доби, а і певних періодів онтогенезу (як у вегетаційних посудинах, так і в польових умовах). За рахунок цього відбувається стабілізація основних параметрів життєдіяльності рослин, що переконливо підтверджується експериментальними результатами, наведеними на рис. 2.

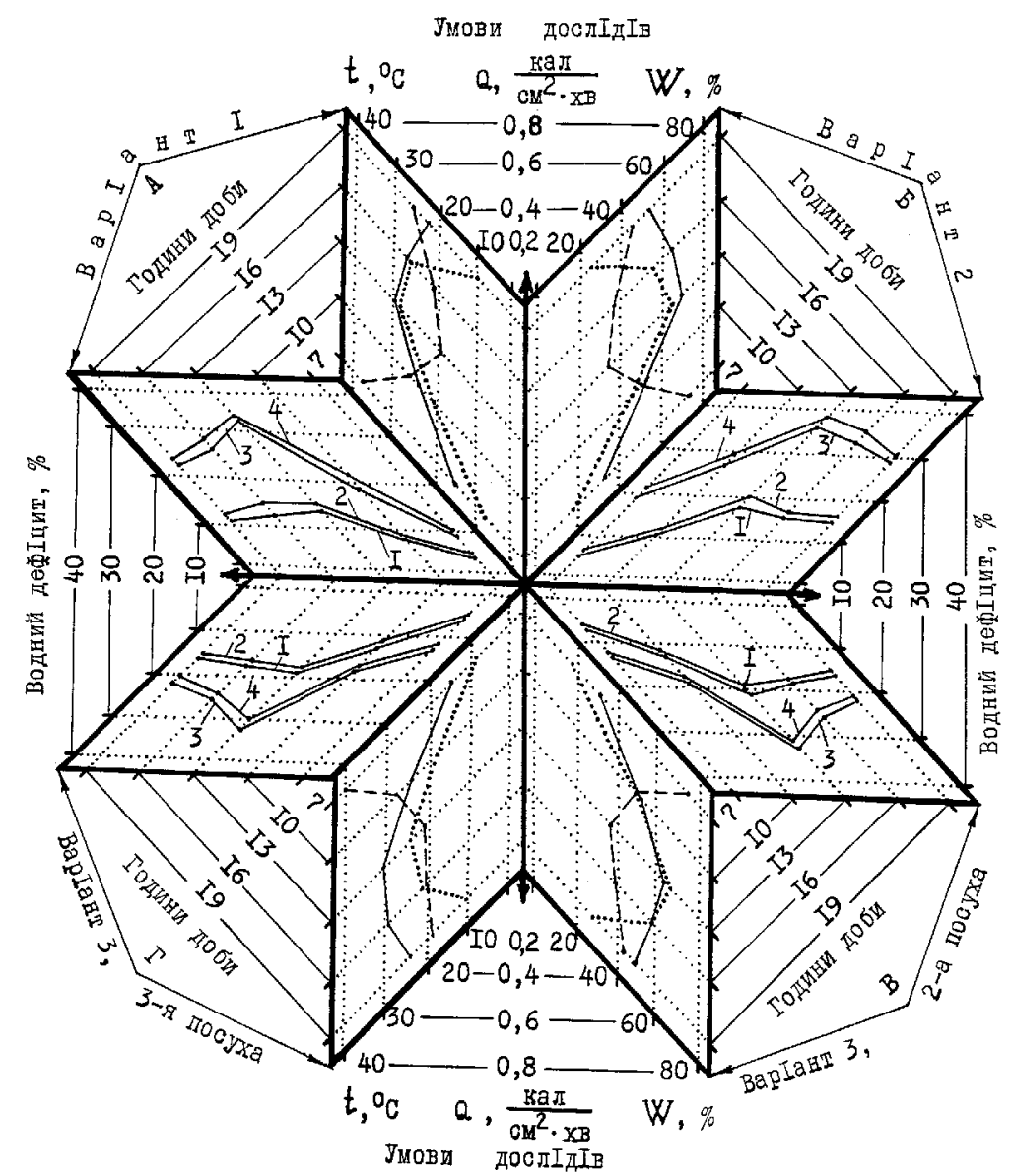

Рис. 2. Водний дефіцит припочаткових листків гібридів кукурудзи

залежно від водозабезпечення: контроль - 1 (гібрид К-271), 2 - (гібрид К-100);

варіанти дослідів - 3, 4 (відповідно); умови дослідів: - температура повітря $(t)$,

---- - відносна вологість повітря $(W), \ldots$ - інтенсивність сонячної радіації $(Q)$

У дослідах знайшов підтвердження той факт, що водний дефіцит (ВД) збільшується у гібридів кукурудзи від нижніх листків до верхніх. При цьому рівень та різниця абсолютних значень цього показника в основному визначаються рівнем водозабезпечення, умовами середовища та онтогенетичним станом рослини [24; 36].

Одним із напрямків робіт у цьому руслі $є$ удосконалення не тільки конструктивних особливостей вегетаційних посудин для вирощування рослин, а і складу поживних сумішей та способів підтримки заданих рівнів водозабезпечення. Найвідомішими з них $€$ : мікропольовий метод А. Ф. Маринчик, який базується на застосуванні вегетаційних посудин без дна, верхня частина яких розміщується на рівні грунту [26] і таким чином модифікується вегетаційний мікроділянковий метод; вегетаційні посудини Х. М. Починка для вирощування рослин просто неба, у яких вперше застосовується повітряна

Вісник Дніпропетровського університету. Біологія, екологія.

Vìsnik Dnìpropetrovs'kogo unìversitetu. Serìa Bìologîa, ekologîâ Visnyk of Dnipropetrovsk University. Biology, ecology. Vìsn. Dnìpropetr. Unìv. Ser. Bìol. Ekol. 2007. 15(1).

ISSN 2310-0842 print ISSN 2312-301X online www.ecology.dp.ua 
камера для забезпечення киснем кореневої системи, а рівень водозабезпечення контролюється водомірною трубкою [32]. Для програмованого моделювання рівня водозабезпечення рослин, здійснення автоматизованого поливу та врахування водовитрат кожною рослиною (дослідним варіантом) Є. О. Казаковим розроблені відповідні установки [1; 19-21] та виконавчий пристрій [18], які при комутуванні здійснюють всі перелічені функції із статистичною обробкою результатів по варіантах.

Вважаючи, що процес водообміну включає не тільки поглинання води рослиною, а і іiі виділення, вчені-дослідники розробили ряд методик для реєстрації цього процесу. Широко відомі хлоркальцієві трубки Х. М. Починка для визначення інтенсивності транспірації [31] та ультратермопсихрометр, розроблений Б. І. Гуляєвим [10], за допомогою яких транспіраційні водовитрати реєструються одночасно $3 \mathrm{CO}_{2}$-обміном (фотосинтезом). Для досліджень водовиділення у вигляді пасоки Є. О. Казаковим із співавторами розроблено автоматизований пристрій, який збирає пасоку за певні проміжки часу у відповідні пробірки колектора [19]. Опосередковану інформацію про транспіраційний процес можна отримати з використанням порометpa, розробленого Б. І. Гуляєвим зі співавторами [11]. За допомогою оригінальної установки для регуляції температури грунту у вегетаційних посудинах М. Ф. Бузановим зі співавторами (ВНІС УААН) на цукрових буряках отримані цікаві результати про вплив рівня водозабезпечення на анатомо-морфологічні параметри, ріст, розвиток і функціонування кореневих систем за умов різних температур [5].

Характерною рисою вітчизняних вчених була і $є$ постійна наукова співпраця 3 фізіологами-водниками як у самій країні, так і за іï межами. Про це свідчать відрядження, стажування, обміни науковою літературою, участь у міжнародних наукових форумах. Розроблена Б. І. Гуляєвим методика переведення значень водного дефіциту у значення водного потенціалу рослинного об'єкта забезпечила порівняння результатів українських і зарубіжних учених [10]. Організація міжнародних семінарів із водного режиму рослин, один із яких проходив у Києві у 1984 році, участь у спільних проектах, одним із яких є фундаментальна монографія «Водный обмен растений» [12], співавторами якої є і українські фізіологи (І. Г. Шматько, ІФРГ НАН України; А. В. Капля та П. С. Славний, Київський національний університет ім. Т. Шевченка) дозволяють констатувати, що вагомий авторитет має українська фітофізіологічна школа в аспекті вивчення водного режиму рослин.

\section{Висновок}

Наведена інформація свідчить про наявність певного генезису формування та становлення вчення про водообмін рослин, у якому українські вчені мають вагомі доробки стосовно розвитку різних напрямків даної проблеми: створення та удосконалення матеріально-технічної бази; розробка та використання сучасних методів і методик; отримання конкретних результатів у теоретичному та практичному контекстах.

\section{Бібліографічні посилання}

1. А. c. 952167 СССР, МКИЗ А 01 G 27/00. Устройство для полива растений / Е. А. Казаков, Б. И. Гуляев, С. М. Казакова, А. С. Оканенко. - Опубл. 21.04.82. - Бюл. № 31.

2. Алексеев А. М. Водный режим растений и влияние на него засухи. - Казань: Татгосиздат, 1948. -355 с.

3. Баранецкий О. В. О периодичности истечения сока травянистых растений и причинах этой периодичности // Тр. СПб. о-ва естествоисп. - 1873. - Т. 4. - Вып. 1. - С. 1-84.

4. Богданов С. М. О минимуме поглощения воды прорастающими семенами // Изв. Петровск. земледельч. акад. - 1886. - Т. 9. - Вып. 1. - С. 1-23.

Вісник Дніпропетровського університету. Біологія, екологія.

Vìsnik Dnìpropetrovs'kogo unìversitetu. Seriâ Bìologîa, ekologîâ Visnyk of Dnipropetrovsk University. Biology, ecology. Vìsn. Dnìpropetr. Unìv. Ser. Bìol. Ekol. 2007. 15(1).

ISSN 2310-0842 print ISSN 2312-301X online www.ecology.dp.ua 
5. Влияние температуры почвы на некоторые физиолого-биохимические процессы у растений сахарной свеклы и её продуктивность / М. Ф. Бузанов, К. А. Маковецкий, Н. Г. Будаковская и др. // Сб. научных трудов по физиологии, анатомии, биохимии и технологии сахарной свеклы. - К.: Б.и., 1971. - С. 362-376.

6. Вотчал Е. Ф. О движении пасоки (воды) в растении: критическое и экспериментальное исследование. - М.: Тип. Кушнерева, 1897. - 390 с.

7. Вотчал Е. Ф. Полевая физиология (нормальная и патологическая) и физиологическое сортоизучение в селекции // Тр. Науч. ин-та селекции. - 1928. - Вып. 2. - С. 209-236.

8. Григорюк И. А. Аденозинфосфатная система и засухоустойчивость растений // Физиология и биохимия культ. растений. - 2001. - Т. 33, № 3. - С. 199-207.

9. Григорюк І. П. Водний і високотемпературний стреси. Молекулярні та фізіологічні механізми стійкості рослин / І. П. Григорюк, М. М. Мусієнко // Фізіологія рослин в Україні на межі тисячоліть. - К.: Фітосоціоцентр, 2001. - Т. 2. - С. 118-129.

10. Фотосинте3, продукционный процесс и продуктивность растений / Б.И.Гуляев, И. И. Рожко, А. Д. Рогаченко и др. - К.: Наукова думка, 1989. - 151 с.

11. Гуляев Б. И. Устьичный порометр и его использование для оценки состояния листового аппарата / Б. И. Гуляев, О. Е. Шведова // Физиология и биохимия культ. растений. 1984. - Т. 16, № 5. - С. 504-506.

12. Водный обмен растений / В. Н. Жолкевич, Н. А. Гусев, А. В. Капля и др. - М.: Наука, 1989. - $256 \mathrm{c}$.

13. Жук О. І. Клітинний ріст рослин за умов водного стресу / О. І. Жук, І. П. Григорюк, Д. М. Гродзинський // Физиология и биохимия культ. растений. - 1999. - Т. 31, № 2. - С. 83-92.

14. Журавлева Н. А. Механизм устьичных движений, продукционный процесс и эволюция. - Новосибирск: Наука, 1992. - 140 с.

15. Заленский В. Р. Материалы к количественной анатомии различных листьев одних и тех же растений (магистерск. дис.) // Изв. Киев. политехн. ин-та. - 1904. - Т. 4, кн. 1. - С. 1-212.

16. Залялов А. А. Физиолого-термодинамический аспект транспорта воды по растению. М.: Наука, 1984. - 136 с.

17. Історія Академії наук України. 1918-1993 / Гол. ред. К. М. Ситник. - К.: Наукова думка, 1994. $-318 \mathrm{c}$.

18. Казаков С. О. Пристрій для автоматизованого поливу рослин у вегетаційних дослідах 3 урахуванням їх індивідуальних водовитрат // Физиология и биохимия культ. растений. 1999. - Т. 31, № 5. - С. 392-396.

19. Казаков Є. О. Методологічні основи постановки експерименту з фізіології рослин. - К.: Фітосоціоцентр, 2000. - 272 с.

20. Усовершенствованная установка для полива растений в вегетационных сосудах / Е. А. Казаков, С. М. Казакова, Б. И. Гуляев, П. А. Ситницкий // Физиология и биохимия культ. растений. - 1988. - Т. 20, № 1. - С. 91-98.

21. Установка для программированного полива растений в мелкоделяночных опытах / Е. А. Казаков, С. М. Казакова, Б. И. Гуляев, П. А. Ситницкий // Физиология и биохимия культ. растений. - 1989. - Т. 21, № 3. - С. 303-306.

22. Казаков Є. О. Посухостійкість рослин та проблема ії вивчення / С. О. Казаков, Т. С. Христова, С. М. Казакова // Питання біоіндикації та екології. - 2000. - Вип. 5, № 1. - С. 3-12.

23. Казаков С. О. Витрати води та продуктивність іiі використання цукровим буряком в залежності від водозабезпечення / С. О. Казаков, Т. Є. Христова, С. М. Казакова // Питання біоіндикації та екології. - 2001. - Вип. 6, № 1. - С. 42-51.

24. Варіабельність впливу води на фотосинтетичний процес / С. О. Казаков, Т. С. Христова, О. С. Пюрко, С. М. Казакова // Матер. Міжнар. науково-практ. конф. «Дні науки 2005». - Д.: Наука і освіта, 2005. - Т. 1. Біологія. - С. 69-72.

25. Колкунов В. В. К вопросу о выработке выносливых к засухам рас культурных растений // Изв. Киев. политехн. ин-та. - 1905. - Вып. 5, кн. 4. - С. 18-31; 1907. - Вып. 7, кн. 1. - С. 1-70.

26. Модификация вегетационного и микрополевого методов с почвенной культурой для сахарной свеклы / А. Ф. Маринчик, Н. А. Мазлумова, Л. М. Пахомова, В. П. Курганский // Пути повышения урожайности полевых культур. - Минск: Ураджай, 1981. - Вып. 12. - С. 119-130.

27. Моргун В. В. Здобутки науковців Інституту фізіології рослин і генетики НАН України за 10 років незалежності України // Физиология и биохимия культ. растений. - 2001. - Т. 33, № 3. - С. 187-198.

Вісник Дніпропетровського університету. Біологія, екологія.

Vìsnik Dnìpropetrovs'kogo unìversitetu. Seriâ Bìologîa, ekologîâ Visnyk of Dnipropetrovsk University. Biology, ecology. Vìsn. Dnìpropetr. Unìv. Ser. Bìol. Ekol. 2007. 15(1).

ISSN 2310-0842 print ISSN 2312-301X online www.ecology.dp.ua 
28. Моргун В. В. Історія розвитку фізіології рослин в Україні / В. В. Моргун, В. К. Мусіяка, В. К. Яворська // Фізіологія рослин в Україні на межі тисячоліть. - К.: Фітосоціоцентр, 2001. - T. 1. - C. 16-19.

29. Мусіснко М. М. Проблеми фітофізіології // Укр. ботан. журнал. - 2006. - Т. 63, № 1. C. $107-114$.

30. Мусієнко М. М. Фізіологія рослин. - К.: Либідь, 2005. - 682 с.

31. Починок Х. Н. Методы биохимического анализа растений. - К.: Наукова думка, 1976. - 334 с.

32. Починок Х. Н. Сосуды для вегетационных опытов под открытым небом // Физиология и биохимия культ. растений. - 1981. - Т. 13, № 5. - С. 541-544.

33. Серга О. Г. Аденозинфосфати і енергетичний заряд в листках сортів озимої пшениці за різного водозабезпечення / О. Г. Серга, М. М. Мусієнко, І. П. Григорюк // Доп. НАН України. - 1999. - № 9. - С. 169-172.

34. Фізіологія рослин в Україні на межі тисячоліть / Під ред. В. В. Моргуна. - К.: Фітосоціоцентр, 2001. - Т. 1. - 435 с.; Т. 2. - 339 с.

35. Шардаков В. С. Определение степени насыщенности водой растительных клеток и тканей // Тез. докл. совещ. по физиологиии растений от Тимирязева до наших дней (4-е резерв. чтение). - М.: Изд-во АН СССР, 1944. - С. 48.

36. Христова Т. С. Стійкість та продуктивність гібридів кукурудзи при моделюванні різних типів посухи. - Автореф. дис. ... канд. біол. наук: 03.00.12. - К., 1997. - 20 с.

37. Шматько И. Г. Устойчивость растений к водному и температурному стрессам / И. Г. Шматько, И. А. Григорюк, О. Е. Шведова. - К.: Наукова думка, 1989. - 224 с.

38. Водный режим растений в связи с действием факторов среды / И.Г.Шматько, С. И. Слухай, Н. И. Шевченко и др. - К.: Наукова думка, 1983. - 199 с.

39. Baranetzky O. W. Über den Einfluss einiger Bedingungen auf die Transpiration der Pflanzen // Bot. Ztg. - 1872. - Vol. 30, N 5. - S. 65-73; N 6. - S. 81-89; N 7. - S. 97-109.

Надійшла до редколегії 12.10.2006

Вісник Дніпропетровського університету. Біологія, екологія.

Vìsnik Dnìpropetrovs'kogo unìversitetu. Serìa Bìologîa, ekologîâ

Visnyk of Dnipropetrovsk University. Biology, ecology. Vìsn. Dnìpropetr. Unìv. Ser. Bìol. Ekol. 2007. 15(1).

ISSN 2310-0842 print ISSN 2312-301X online www.ecology.dp.ua 